\title{
REVIEWS
}

\section{Improvement Science and Implementation Science in Cancer Care: Identifying Areas of Synergy and Opportunities for Further Integration}

\author{
Devon K. Check, PhD ' , Leah L. Zullig, PhD ${ }^{1,2}$, Melinda M. Davis, PhD ${ }^{3,4}$, \\ Louise Davies, MD ${ }^{5,6,7}$, David Chambers, DPhil ${ }^{8}$, Linda Fleisher, $P h D^{9}$, \\ Samantha J. Kaplan, PhD ${ }^{10}$, Enola Proctor, PhD ${ }^{11}$, Shoba Ramanadhan, $S c D^{12}$, \\ Florian R. Schroeck, MD ${ }^{5,6,13}$, Angela M. Stover, $P h D^{14}$, and Bogda Koczwara, MD ${ }^{15}$
}

'Department of Population Health Sciences and Duke Cancer Institute, Duke University Medical Center, Durham, NC, USA; ${ }^{2}$ Center of Innovation to Accelerate Discovery and Practice Transformation (ADAPT), Durham Veterans Affairs Health Care System, Durham, NC, USA; ${ }^{3}$ Oregon Rural Practice-based Research Network and Department of Family Medicine, Oregon Health \& Science University, Portland, OR, USA; ${ }^{4}$ School of Public Health, Oregon Health \& Science University and Portland State University, Portland, OR, USA; ${ }^{5}$ The VA Outcomes Group, White River Junction VA Medical Center, Hartford, VT, USA; ${ }^{6}$ The Dartmouth Institute for Health Policy \& Clinical Practice, Dartmouth College, Hanover, NH, USA;

${ }^{7}$ Department of Surgery - Otolaryngology Head \& Neck Surgery, Geisel School of Medicine at Dartmouth, Hanover, NH, USA; ${ }^{8}$ Division of Cancer Control and Population Sciences, National Cancer Institute, Bethesda, MD, USA; ${ }^{9}$ Fox Chase Cancer Center, Philadelphia, PA, USA; ${ }^{10}$ Duke University Medical Center Library \& Archives, Duke University School of Medicine, Durham, NC, USA; " The Brown School at Washington University in St. Louis, St. Louis, MO, USA; ${ }^{12}$ Department of Social and Behavioral Sciences, Harvard T.H. Chan School of Public Health, Boston, MA, USA;

${ }^{13}$ Section of Urology and Norris Cotton Cancer Center, Dartmouth Hitchcock Medical Center, Lebanon, PA, USA; ${ }^{14}$ Department of Health Policy and Management, Gillings School of Global Public Health, Lineberger Comprehensive Cancer Center, University of North Carolina at Chapel Hill, Chapel Hill, NC, USA; ${ }^{15}$ Flinders University, Adelaide, Australia.

Efforts to improve cancer care primarily come from two fields: improvement science and implementation science. The two fields have developed independently, yet they have potential for synergy. Leveraging that synergy to enhance alignment could both reduce duplication and, more importantly, enhance the potential of both fields to improve care. To better understand potential for alignment, we examined 20 highly cited cancer-related improvement science and implementation science studies published in the past 5 years, characterizing and comparing their objectives, methods, and approaches to practice change. We categorized studies as improvement science or implementation science based on authors' descriptions when possible; otherwise, we categorized studies as improvement science if they evaluated efforts to improve the quality, value, or safety of care, or implementation science if they evaluated efforts to promote the implementation of evidence-based interventions into practice. All implementation studies (10/10) and most improvement science studies $(6 / 10)$ sought to improve uptake of evidencebased interventions. Improvement science and implementation science studies employed similar approaches to change practice. For example, training was employed in 8/10 implementation science studies and 4/10 improvement science studies. However, improvement science and implementation science studies used different terminology to describe similar concepts and emphasized different methodological aspects in reporting. Only 4/20 studies (2 from each category) described using a formal theory or conceptual framework to guide program development. Most studies were multi-site (10/10 implementation

Received September 2, 2019

Accepted August 11, 2020

Published online August 31, 2020 science and 6/10 improvement science) and a minority ( 2 from each category) used a randomized design. Based on our review, cancer-related improvement science and implementation science studies use different terminology and emphasize different methodological aspects in reporting but share similarities in purpose, scope, and methods, and are at similar levels of scientific development. The fields are well-positioned for alignment. We propose that next steps include harmonizing language and cross-fertilizing methods of program development and evaluation.

KEY WORDS: implementation science; improvement science; quality improvement; cancer.

$\mathrm{J}$ Gen Intern Med 36(1):186-95

DOI: $10.1007 / \mathrm{s} 11606-020-06138-\mathrm{w}$

(c) Society of General Internal Medicine 2020

\section{INTRODUCTION}

In cancer prevention and control, the adoption of evidence into practice remains slow and uneven across regions and care delivery settings, leading to unwarranted variation in cancer care delivery and deficits in quality and safety. In 2013, the National Academy of Medicine (formerly the Institute of Medicine) described cancer care in the USA as a "system in crisis," calling for efforts to improve accessibility, coordination, and patient centeredness and to better integrate research evidence into oncology practice. ${ }^{1}$ Similar concerns have been raised globally, particularly in low- and middle-income countries. ${ }^{2}$

Efforts to improve cancer care delivery in the USA and abroad are driven primarily by two fields: improvement 
science and implementation science. Broadly, improvement science refers to systems-level efforts to improve the quality, value, and safety of health care. ${ }^{3}$ Implementation science refers to efforts to promote the systematic uptake of evidence-based interventions into practice and policy. ${ }^{4} \mathrm{Al}-$ though their goals are complementary, the two fields have developed independently from different philosophical underpinnings: Improvement science from industry, takes a more pragmatic approach to the reduction of poor performance in health, ${ }^{5}$ whereas implementation science from behavioral science focuses on a need to change behavior across multiple levels of influence to adopt and sustain new evidence in practice. ${ }^{6}$ The fields interact sporadically and remain relatively isolated from one another with respect to terminology, methodology, and integration within health care delivery systems. ${ }^{4}$

Due to their relative isolation, implementation and improvement science have not realized potential synergies to drive positive change in cancer care delivery. As a result, gaps and inequities in the delivery of high-quality, evidence-based cancer care persist across the continuum of care from prevention to treatment to survivorship and end-of-life care. We hypothesize that each discipline has qualities the other could benefit from, and that aligning and cross-fertilizing the fields could reduce silos and duplication, expand the range of methodologies available to those working to improve cancer care delivery, and potentially accelerate the process of improvement. To better understand how implementation science and improvement science are currently being applied to advance cancer care delivery, and to characterize commonalities and differences in the scope and methodology of the two fields, we conducted a review of highly cited improvement science and implementation science studies in cancer care. Specifically, we considered similarities and differences in their objectives, methods, and approaches to practice change. Our objective was to generate preliminary data to inform future efforts to enhance alignment and cross fertilization between the two fields. Our long-term goal is to promote knowledge sharing across the fields to accelerate improvements in cancer care delivery.

\section{METHODS}

With support from a medical librarian (SJK), we searched PubMed for articles published between January 1, 2014, and March 1, 2019, that included terms related to "cancer" and "implementation" or "improvement" in their titles and/or abstracts. We limited our search to 17 peer-reviewed journals commonly accessed by the research team that regularly publish implementation science and/or improvement science studies in the area of cancer care (Table 1). PubMed indexes all 17 of these journals, so it was possible to search all 17 using only PubMed. Details of our PubMed search strategy are presented in Table 2.
Table 1 Peer-Reviewed Journals Included in the PubMed Search

\begin{tabular}{|c|c|c|}
\hline Journal & $\begin{array}{l}\text { PubMed } \\
\text { abbreviation }\end{array}$ & $\begin{array}{l}\text { Impact } \\
\text { factor }\end{array}$ \\
\hline Journal of Nursing Care Quality & J Nurs Care Qual & 1.191 \\
\hline Research Nursing in Health & Res Nurs Health & 1.678 \\
\hline $\begin{array}{l}\text { International Journal for Quality } \\
\text { in Healthcare }\end{array}$ & $\begin{array}{l}\text { Int J Qual Health } \\
\text { Care }\end{array}$ & 1.829 \\
\hline BMC Health Services Research* & $\begin{array}{l}\text { BMC Health Serv } \\
\text { Res }\end{array}$ & 1.932 \\
\hline Clinical and Translational Science & Clin Transl Sci & 1.954 \\
\hline $\begin{array}{l}\text { Journal of Clinical and Translation } \\
\text { Science }\end{array}$ & J Clin Transl Sci & 1.954 \\
\hline Journal of Advanced Nursing & J Adv Nurs & 2.267 \\
\hline Journal of Oncology Practice* & J Oncol Pract & 2.509 \\
\hline $\begin{array}{l}\text { Journal of the American Board of } \\
\text { Family Medicine* }\end{array}$ & $\begin{array}{l}\text { J Am Board Fam } \\
\text { Med }\end{array}$ & 2.515 \\
\hline $\begin{array}{l}\text { Translational Behavioral } \\
\text { Medicine* }\end{array}$ & Transl Behav Med & 2.521 \\
\hline Medical Care* & Med Care & 3.081 \\
\hline $\begin{array}{l}\text { American Journal of Public } \\
\text { Health* }\end{array}$ & Am J Public & 4.138 \\
\hline Implementation science* & Implement Sci & 4.345 \\
\hline $\begin{array}{l}\text { American Journal of Preventive } \\
\text { Medicine* }\end{array}$ & Am J Prev Med & 4.527 \\
\hline $\begin{array}{l}\text { Journal of General Internal } \\
\text { Medicine* }\end{array}$ & $\mathrm{J}$ Gen Intern Med & 4.606 \\
\hline BMJ Quality and Safety & BMJ Qual Saf & 7.226 \\
\hline Annual Review of Public Health & $\begin{array}{l}\text { Annu Rev Public } \\
\text { Health }\end{array}$ & 9.491 \\
\hline
\end{tabular}

*Published one or more studies included in the final review and analysis

Using the Rayyan screening tool, ${ }^{7}$ two authors (DKC and LLZ) reviewed the titles and abstracts of all articles returned by the PubMed search, to make decisions about inclusion. First, we developed a coding structure for inclusion and exclusion criteria by independently reviewing the titles and abstracts of the same 50 articles, then meeting to resolve discrepancies and clarify decision rules (e.g., to allow for inclusion of de-implementation studies). Next, we each reviewed half of the remaining articles for inclusion, noting articles that required further discussion. Decisions about the inclusion and categorization of these articles were reached through consensus-based discussion, with a third author (BK) providing adjudication. Finally, within each category (implementation science or improvement science), we ordered included articles by number of citations, using the Web of Science Citation Index. We selected the 10 most highly cited articles from each category for inclusion in the analysis, using number of citations as an indicator of study impact. ${ }^{8,9}$

When reviewing, we considered articles eligible for inclusion if they evaluated interventions or strategies aimed at improving cancer care delivery and related to implementation science or improvement science. Specifically, articles were included if their titles and/or abstracts made specific reference to implementation science (e.g., implementation strategy or evidence-based intervention) or improvement science (e.g., quality improvement or process improvement), or if they met commonly used definitions of either discipline. Based on these definitions, implementation science studies evaluated efforts to promote the adoption and implementation of evidencebased interventions into practice, ${ }^{4}$ and improvement science studies evaluated efforts to improve the quality, value, or 
Table 2 PubMed Search Strategy

\begin{tabular}{|c|c|}
\hline Search \# & Query \\
\hline 1-Journals (ISSN) & $\begin{array}{l}\text { 1353-4505 OR 2044-5415 OR 1057-3631 OR 0309-2402 OR 1748-5908 OR 1613-9860 OR 0025-7079 OR } \\
0163-7525 \text { OR 0160-6891 OR 1554-7477 OR 1752-8054 OR 0090-0036 OR 0749-3797 OR 1557-2625 OR } \\
0884-8734 \text { OR 1472-6963 OR 2059-8661 }\end{array}$ \\
\hline 2-Terms related to "Cancer" & $\begin{array}{l}\text { Neoplasms[Mesh] OR neoplasms[tiab] OR cancer[tiab] OR cancers[tiab] OR cancerous[tiab] OR tumor[tiab] } \\
\text { OR tumour[tiab] OR tumors[tiab] OR tumours[tiab] OR carcinoma[tiab] OR carcinomas[tiab] }\end{array}$ \\
\hline $\begin{array}{l}\text { 3-Terms related to "Improve" OR } \\
\text { "Implement" }\end{array}$ & $\begin{array}{l}\text { (implement[tw] OR implementing[tw] OR implemented[tw] OR implements[tw] OR adoption[tw] OR } \\
\text { adopt[tw] OR adopted[tw] OR adopts[tw] OR uptake[tw] OR use[tw] OR dissemination[tw] OR } \\
\text { disseminating[tw] OR disseminated[tw] OR "knowledge transfer"[tw] OR "knowledge translation"[tw]) OR } \\
\text { (improvement[tw] OR improve[tw] OR improved[tw] OR improves[tw] OR improving[tw] OR increase[tw] } \\
\text { OR increasing[tw] OR increases[tw] OR increased[tw] OR reduce[tw] OR reducing[tw] OR reduces[tw] OR } \\
\text { reduced[tw] OR decrease[tw] OR decreased[tw] OR decreasing[tw] OR decreases[tw]) }\end{array}$ \\
\hline 4 & 1 AND 2 AND 3 \\
\hline 5-Dates & Published between January $1^{\text {st }}, 2014$ and March $1^{\text {st }}, 2019$ \\
\hline TOTAL SEARCH BLOCK & $\begin{array}{l}(((1353-4505 \text { OR 2044-5415 OR 1057-3631 OR 0309-2402 OR 1748-5908 OR 1613-9860 OR 0025-7079 } \\
\text { OR 0163-7525 OR 0160-6891 OR 1554-7477 OR 1752-8054 OR 0090-0036 OR 0749-3797 OR 1557-2625 } \\
\text { OR 0884-8734 OR 1472-6963 OR 2059-8661)) AND (Neoplasms[Mesh] OR neoplasms[tiab] OR } \\
\text { cancer[tiab] OR cancers[tiab] OR cancerous[tiab] OR tumor[tiab] OR tumour[tiab] OR tumors[tiab] OR } \\
\text { tumours[tiab] OR carcinoma[tiab] OR carcinomas[tiab])) AND ((implement[tw] OR implementing[tw] OR } \\
\text { implemented[tw] OR implements[tw] OR adoption[tw] OR adopt[tw] OR adopted[tw] OR adopts[tw] OR } \\
\text { uptake[tw] OR use[tw] OR dissemination[tw] OR disseminating[tw] OR disseminated[tw] OR "knowledge } \\
\text { transfer"[tw] OR “knowledge translation"[tw]) OR (improvement[tw] OR improve[tw] OR improved[tw] OR } \\
\text { improves[tw] OR improving[tw] OR increase[tw] OR increasing[tw] OR increases[tw] OR increased[tw] OR } \\
\text { reduce[tw] OR reducing[tw] OR reduces[tw] OR reduced[tw] OR decrease[tw] OR decreased[tw] OR } \\
\text { decreasing[tw] OR decreases[tw])) }\end{array}$ \\
\hline
\end{tabular}

Search conducted on March 1, 2019

safety of care. ${ }^{3}$ Included studies were categorized as implementation science or improvement science according to authors' descriptions where possible, or else according to these definitions.

Studies could address any aspect of cancer care, from prevention, to treatment, to end-of-life care. We excluded commentaries, reviews, case reports, and practice guidelines; studies that did not relate to cancer prevention or control; and cancer prevention or control studies focused on clinical effectiveness.

Four authors (DKC, LLZ, MD, BK) developed an abstraction form based on improvement science and implementation science concepts previously described by members of our team ${ }^{4}$ in addition to the Standards for Reporting Implementation Studies (STaRI) ${ }^{10}$ and Standards for Quality Improvement Reporting Excellence (SQUIRE) $2.0^{3}$ guidelines. These standards were established in 2015 and 2017, respectively. The SQUIRE 2.0 guidelines are intended to guide research using any method to improve healthcare. The StaRI guidelines apply more specifically to studies that aim to improve the implementation and scaling up of effective healthcare interventions (or discontinuation of ineffective or harmful interventions).

We conducted a pilot test of the abstraction form in which four authors (DKC, LLZ, MD, BK) abstracted data from five common articles, to refine the data abstraction process and ensure consistency. Each of the four authors then independently abstracted a subset of the 20 articles (10 implementation science and 10 improvement science). One author (DKC) reviewed all abstracted information for accuracy. The final set of 10 implementation science and 10 improvement science studies were then characterized and compared with respect to their objectives, methods, and approaches to practice change.

\section{RESULTS}

\section{Search Results}

The PubMed search returned 1,381 unique articles. After title and abstract review, 90 studies categorized as implementation or improvement science remained. Reasons for the exclusion of articles are shown in Figure 1. From these 90 studies, we retained the 10 most highly cited studies from each category for inclusion in the analysis, for a total of 20 studies. Included studies were cited an average of 8 times (mean: 11 for improvement science and 6 for implementation science).

\section{Basic Study Characteristics}

Most articles (14/20) reported on studies conducted in the USA. Studies addressed cancer prevention $(2 / 20),{ }^{11,12}$ screening $(8 / 20),{ }^{13-20}$ diagnosis $(1 / 20),{ }^{21}$ treatment $(5 / 20),{ }^{22-26}$ and supportive, palliative, or psychosocial care (4/20). ${ }^{27-30}$ Implementation science studies (8/10) typically focused on cancer prevention or screening, while improvement science studies were more distributed across the cancer care continuum. Studies had been published in nine of the 17 searched journals, including one cancer-specific journal (Table 3).

\section{Study Objectives, Setting, and Design}

Of the 10 studies categorized as implementation science, 9 sought to improve uptake of an evidence-based practice (e.g., cervical cancer screening) or program (e.g., a skin cancer prevention program). The final implementation science study focused on discontinuation of a practice lacking evidence of benefit, namely PSA screening for men aged 75 years or older. $^{16}$ 
1,381 articles from PubMed search

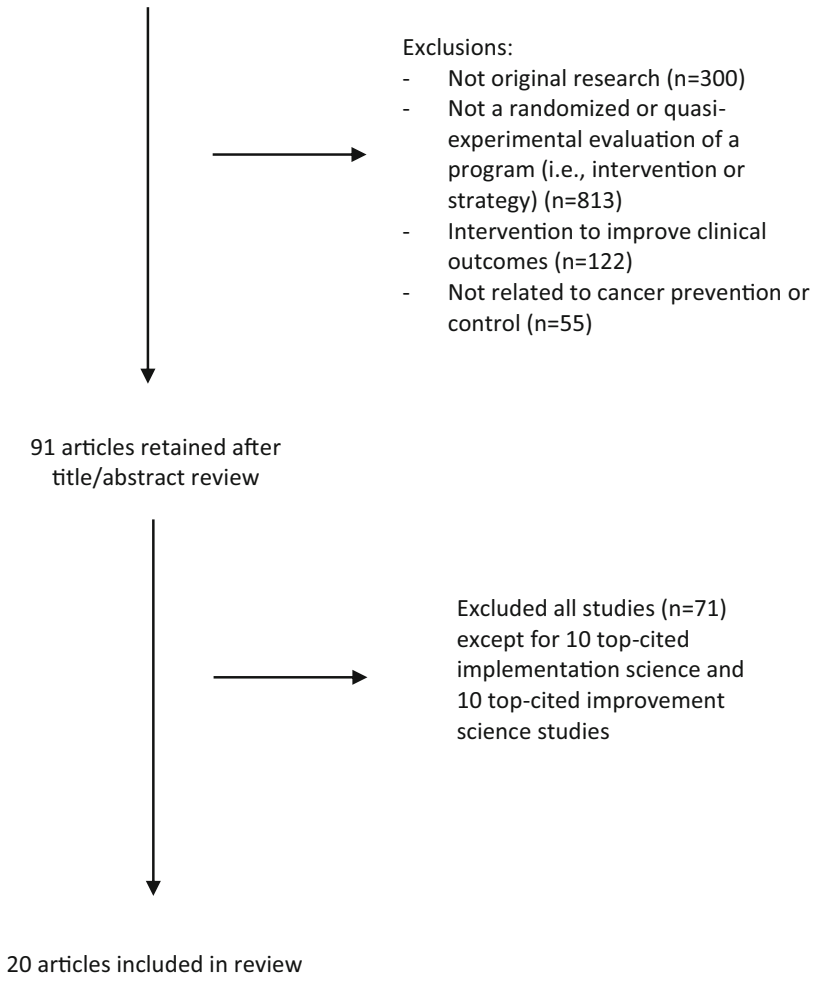

Figure 1 Reasons for exclusion of studies.

Among the studies categorized as improvement science, 6/10 aimed to improve uptake of evidence-based and/or guideline-recommended practices, including, for example, cancer screening, emotional distress screening, radiation treatment peer review, and timely antibiotic administration for febrile neutropenia. $19,20,22,24,26$, 29 The remaining improvement science studies sought to improve clinical or utilization outcomes such as unplanned readmissions, reducing costs, and/or addressing logistical issues in care delivery.

All (10/10) studies categorized as implementation science and 6/10 studies categorized as improvement science ${ }^{19-23,29}$ were conducted across multiple sites (e.g., clinics, hospitals, schools). For most (7/10) multi-site implementation science studies, and all (6/6) multi-site improvement science studies, the multiple study sites were part of the same health system or network.

Table 3 shows that implementation and improvement science studies typically used basic observational study designs, such as a single group pre-test post-test design (4/10 implementation science and 6/10 improvement science). ${ }^{12-15,23-26 \text {, }}$ ${ }^{29}$ Only 4/20 studies (2/10 implementation science and 2/10 improvement science) $)^{11,20,21,28}$ used a randomized controlled trial (RCT) design to evaluate the program of interest.

\section{Development and Components of the Program Under Study}

Implementation science studies (6/10) referred to programs designed to promote practice change as "strategies" or as a collective "strategy" 11, 13, 15, 17, 27, 28 while improvement science studies (6/10) used the term "intervention." 19-21, 26, 29, ${ }^{30}$ The remaining improvement science studies (4/10) used a more specific term to describe the program under study, for example, "care pathway," or referred to a broad approach, such as "change management initiative."

Across all 20 studies, only 4 ( 2 from each category) described a theoretical or conceptual basis for development of the program (Table 3 ). Both implementation science studies ${ }^{11}$, ${ }^{18}$ applied the Diffusion of Innovations Theory in developing the program under study; one of these studies also used Social Cognitive Theory. ${ }^{11}$ One of the improvement science studies described a specific "conceptual model of primary care delivery" as the basis for their program, ${ }^{19}$ and another used the Community Health Advisors Network Model. ${ }^{24}$

Studies categorized as improvement science generally provided more information about the context in which care delivery gaps were identified and prioritized, and solutions developed. For example, 4/10 improvement science studies described conducting a current state analysis to identify or better understand the problem; ${ }^{22}$, $25,26,293 / 10$ described convening a group of local stakeholders to address the problem;2, 23, 29 and 2/10 described conducting a barriers assessment to inform program development. ${ }^{22}{ }^{29}$ Descriptions of the context surrounding program development in implementation science studies generally contained less detail; 4/10 studies in this category provided baseline data to 
Table 3 Study Details

\begin{tabular}{|c|c|c|c|c|c|c|}
\hline \multicolumn{7}{|c|}{ Studies categorized as implementation science } \\
\hline $\begin{array}{l}\text { Author, journal, } \\
\text { year, country }\end{array}$ & Title & Objective(s) & Setting & $\begin{array}{l}\text { Evaluation } \\
\text { design }\end{array}$ & Use of theory & $\begin{array}{l}\text { Approaches to } \\
\text { practice change }\end{array}$ \\
\hline $\begin{array}{l}\text { Arrossi, } \\
\text { Implement Sci, } \\
\text { 2017, Argentina }\end{array}$ & $\begin{array}{l}\text { Evaluation of scaling-up of } \\
\text { HPV self-collection of- } \\
\text { fered by community health } \\
\text { workers (CHWs) at home } \\
\text { visits to increase screening } \\
\text { among socially vulnerable } \\
\text { under-screened women in } \\
\text { Jujuy Province, Argentina }\end{array}$ & $\begin{array}{l}\text { To (1) evaluate the ef- } \\
\text { fectiveness of an } \\
\text { evidence-based self- } \\
\text { collection strategy on } \\
\text { screening uptake } \\
\text { among under-screened } \\
\text { women when imple- } \\
\text { mented province-wide; } \\
\text { (2) evaluate adoption of } \\
\text { the strategy by CHWs; } \\
\text { and (3) identify imple- } \\
\text { mentation barriers }\end{array}$ & $\begin{array}{l}\text { Jujuy province public } \\
\text { health system, including } \\
270 \text { primary health care } \\
\text { centers and } 700 \mathrm{CHW}\end{array}$ & $\begin{array}{l}\text { Single-group } \\
\text { pre-test post- } \\
\text { test design }\end{array}$ & None & $\begin{array}{l}\text { Education/ } \\
\text { training }\end{array}$ \\
\hline $\begin{array}{l}\text { Bharel, Am J Pub } \\
\text { Health, 2015, } \\
\text { USA }\end{array}$ & $\begin{array}{l}\text { Eliminating Health } \\
\text { Disparities: Innovative } \\
\text { Methods to Improve } \\
\text { Cervical Cancer Screening } \\
\text { in a Medically } \\
\text { Underserved Population }\end{array}$ & $\begin{array}{l}\text { To improve cervical } \\
\text { cancer screening rates } \\
\text { among homeless } \\
\text { women }\end{array}$ & $\begin{array}{l}\text { Boston Health Care for the } \\
\text { Homeless program } \\
\text { (Boston, MA), which } \\
\text { includes } 70 \text { community } \\
\text { sites }\end{array}$ & $\begin{array}{l}\text { Single group } \\
\text { pre-test post- } \\
\text { test design }\end{array}$ & None & $\begin{array}{l}\text { Education/ } \\
\text { training; decision } \\
\text { support; } \\
\text { feedback; } \\
\text { workflow } \\
\text { modification; } \\
\text { rapid cycle } \\
\text { testing }\end{array}$ \\
\hline $\begin{array}{l}\text { Glanz, Am J Pub } \\
\text { Health, 2015, } \\
\text { USA }\end{array}$ & $\begin{array}{l}\text { Randomized Trial of Two } \\
\text { Dissemination Strategies } \\
\text { for a Skin Cancer } \\
\text { Prevention Program in } \\
\text { Aquatic Settings }\end{array}$ & $\begin{array}{l}\text { To evaluate the effects } \\
\text { of } 2 \text { strategies (basic vs. } \\
\text { enhanced) for } \\
\text { dissemination of the } \\
\text { Pool Cool skin cancer } \\
\text { prevention program on } \\
\text { (1) program implemen- } \\
\text { tation, maintenance, } \\
\text { and sustainability; (2) } \\
\text { improvements in orga- } \\
\text { nizational and environ- } \\
\text { mental supports for sun } \\
\text { protection at swimming } \\
\text { pools; and (3) sun pro- } \\
\text { tection habits and sun- } \\
\text { burns among children }\end{array}$ & $\begin{array}{l}\text { Outdoor swimming pools } \\
\text { in } 33 \text { metropolitan areas } \\
\text { across the USA }\end{array}$ & $\begin{array}{l}\text { Randomized } \\
\text { controlled trial } \\
(\mathrm{RCT})\end{array}$ & $\begin{array}{l}\text { Social cognitive } \\
\text { theory; diffusion } \\
\text { of innovations } \\
\text { theory; and } \\
\text { theories of } \\
\text { organizational } \\
\text { change }\end{array}$ & $\begin{array}{l}\text { Education/ } \\
\text { training; } \\
\text { feedback }\end{array}$ \\
\hline $\begin{array}{l}\text { Mader, Am J } \\
\text { Fam Med } 2016 \\
\text { USA }\end{array}$ & $\begin{array}{l}\text { A Practice Facilitation and } \\
\text { Academic Detailing } \\
\text { Intervention Can Improve } \\
\text { Cancer Screening Rates in } \\
\text { Primary Care Safety Net } \\
\text { Clinics }\end{array}$ & $\begin{array}{l}\text { To evaluate the efficacy } \\
\text { and feasibility of an } \\
\text { academic detailing and } \\
\text { practice facilitation } \\
\text { strategy to increase } \\
\text { screening rates }\end{array}$ & $\begin{array}{l}3 \text { practice-based research } \\
\text { networks in Central and } \\
\text { Western New York, in- } \\
\text { cluding } 23 \text { federally quali- } \\
\text { fied health centers }\end{array}$ & $\begin{array}{l}\text { Single group } \\
\text { pre-test post- } \\
\text { test design }\end{array}$ & None & $\begin{array}{l}\text { Education/ } \\
\text { training; } \\
\text { workflow } \\
\text { modification }\end{array}$ \\
\hline $\begin{array}{l}\text { McCarter, Transl } \\
\text { Behav Med, } \\
\text { 2018, Australia }\end{array}$ & $\begin{array}{l}\text { Effectiveness of clinical } \\
\text { practice change strategies } \\
\text { in improving dietitian care } \\
\text { for head and neck cancer } \\
\text { patients according to } \\
\text { evidence-based clinical } \\
\text { guidelines: a stepped- } \\
\text { wedge RCT }\end{array}$ & $\begin{array}{l}\text { To assess the impact of } \\
\text { practice change } \\
\text { strategies on } \\
\text { implementation of } \\
\text { clinical practice } \\
\text { guidelines for } \\
\text { nutritional management } \\
\text { of patients with head } \\
\text { and neck cancer }\end{array}$ & $\begin{array}{l}\text { Radiotherapy departments } \\
\text { in } 5 \text { hospitals }\end{array}$ & $\begin{array}{l}\text { Stepped-wedge } \\
\text { RCT }\end{array}$ & None & $\begin{array}{l}\text { Education/ } \\
\text { training; decision } \\
\text { support; feedback }\end{array}$ \\
\hline $\begin{array}{l}\text { Shelton, J Gen } \\
\text { Intern Med, 2015, } \\
\text { USA }\end{array}$ & $\begin{array}{l}\text { Reducing PSA-Based } \\
\text { Prostate Cancer Screening } \\
\text { in Men Aged } 75 \text { Years and } \\
\text { Older with the Use of } \\
\text { Highly Specific Comput- } \\
\text { erized Clinical Decision } \\
\text { Support }\end{array}$ & $\begin{array}{l}\text { To assess whether } \\
\text { implementation of a } \\
\text { point-of-care computer- } \\
\text { ized clinical decision } \\
\text { support tool resulted in } \\
\text { a reduction in inappro- } \\
\text { priate PSA screening in } \\
\text { the elderly }\end{array}$ & $\begin{array}{l}\text { All outpatient clinics in the } \\
\text { Veterans Affairs Greater } \\
\text { Los Angeles Healthcare } \\
\text { System including a } \\
\text { hospital-based primary } \\
\text { care clinic, two ambulatory } \\
\text { care centers, and eight } \\
\text { community-based outpa- } \\
\text { tient clinics }\end{array}$ & $\begin{array}{l}\text { Interrupted } \\
\text { time series }\end{array}$ & None & Decision support \\
\hline $\begin{array}{l}\text { Stock, } \\
\text { Implementation } \\
\text { Science, 2015, } \\
\text { Canada }\end{array}$ & $\begin{array}{l}\text { Mailed participant } \\
\text { reminders are associated } \\
\text { with improved } \\
\text { colonoscopy uptake after a } \\
\text { positive FOBT result in } \\
\text { Ontario's }\end{array}$ & $\begin{array}{l}\text { To assess the effect of } \\
\text { two strategies on } \\
\text { colonoscopy uptake } \\
\text { following positive fecal } \\
\text { occult blood (FOBT) } \\
\text { screening }\end{array}$ & $\begin{array}{l}\text { Ontario's province-wide } \\
\text { ColonCancerCheck pro- } \\
\text { gram, which provides } \\
\text { FOBT kits, distributed by } \\
\text { primary care providers to } \\
\text { eligible adults (an estimat- } \\
\text { ed } 3.9 \text { million individuals) }\end{array}$ & $\begin{array}{l}\text { Segmented } \\
\text { time series } \\
\text { regression }\end{array}$ & None & $\begin{array}{l}\text { Decision support; } \\
\text { workflow } \\
\text { modification }\end{array}$ \\
\hline
\end{tabular}


Table 3. (continued)

\begin{tabular}{|c|c|c|c|c|c|c|}
\hline \multicolumn{7}{|c|}{ Studies categorized as implementation science } \\
\hline \multirow[t]{2}{*}{$\begin{array}{l}\text { Author, journal, } \\
\text { year, country }\end{array}$} & Title & Objective(s) & Setting & $\begin{array}{l}\text { Evaluation } \\
\text { design }\end{array}$ & Use of theory & $\begin{array}{l}\text { Approaches to } \\
\text { practice change }\end{array}$ \\
\hline & $\begin{array}{l}\text { ColonCancerCheck } \\
\text { program }\end{array}$ & & & & & \\
\hline $\begin{array}{l}\text { Tu, Implement } \\
\text { Sci, 2014, USA }\end{array}$ & $\begin{array}{l}\text { Adaptation of an evidence- } \\
\text { based intervention to pro- } \\
\text { mote colorectal cancer } \\
\text { (CRC) screening: a quasi- } \\
\text { experimental study }\end{array}$ & $\begin{array}{l}\text { To investigate the } \\
\text { adaptation of an } \\
\text { evidence-based inter- } \\
\text { vention designed to in- } \\
\text { crease CRC screening } \\
\text { in one limited English- } \\
\text { proficient (LEP) popu- } \\
\text { lation (Chinese), for } \\
\text { another LEP group } \\
\text { (Vietnamese) and to } \\
\text { investigate effective- } \\
\text { ness of the adapted } \\
\text { intervention }\end{array}$ & $\begin{array}{l}\text { Two primary care } \\
\text { practices affiliated with the } \\
\text { same community health } \\
\text { center in Seattle, } \\
\text { Washington }\end{array}$ & $\begin{array}{l}\text { Two group pre- } \\
\text { test post-test } \\
\text { design }\end{array}$ & $\begin{array}{l}\text { Diffusion of } \\
\text { innovations } \\
\text { theory }\end{array}$ & $\begin{array}{l}\text { Education/ } \\
\text { training; decision } \\
\text { support }\end{array}$ \\
\hline $\begin{array}{l}\text { Vanderpool, Am } \\
\text { J of Prev Med, } \\
2015, \text { USA }\end{array}$ & $\begin{array}{l}\text { Implementation and } \\
\text { Evaluation of a School- } \\
\text { Based Human Papilloma- } \\
\text { virus Vaccination Program } \\
\text { in Rural Kentucky }\end{array}$ & $\begin{array}{l}\text { To design, implement, } \\
\text { and evaluate the impact } \\
\text { of a school-based HPV } \\
\text { vaccination program on } \\
\text { vaccine initiation and } \\
\text { completion among stu- } \\
\text { dents in two high } \\
\text { schools }\end{array}$ & $\begin{array}{l}2 \text { high schools in } \\
\text { Kentucky, located in the } \\
\text { same county }\end{array}$ & $\begin{array}{l}\text { Single group } \\
\text { pre-test post- } \\
\text { test design }\end{array}$ & None & $\begin{array}{l}\text { Education/ } \\
\text { training }\end{array}$ \\
\hline $\begin{array}{l}\text { Walling, Journal } \\
\text { of Oncology } \\
\text { Practice, } 2017 \text {, } \\
\text { USA }\end{array}$ & $\begin{array}{l}\text { Effect and Efficiency of an } \\
\text { Embedded Palliative Care } \\
\text { Nurse Practitioner in an } \\
\text { Oncology Clinic }\end{array}$ & $\begin{array}{l}\text { To determine whether } \\
\text { implementation of a } \\
\text { palliative care nurse } \\
\text { practitioner (NP) within } \\
\text { an oncology clinic } \\
\text { using comprehensive } \\
\text { implementation strate- } \\
\text { gies and a shared men- } \\
\text { tal model improves the } \\
\text { quality of supportive } \\
\text { care provided to pa- } \\
\text { tients }\end{array}$ & $\begin{array}{l}2 \text { oncology clinics in the } \\
\text { University of California } \\
\text { Los Angeles health system }\end{array}$ & $\begin{array}{l}\text { Two group pre- } \\
\text { test post-test } \\
\text { design }\end{array}$ & None & $\begin{array}{l}\text { Education/ } \\
\text { training; } \\
\text { workflow } \\
\text { modification }\end{array}$ \\
\hline $\begin{array}{l}\text { Berkowitz, } 2015 \text {, } \\
\text { J Gen Intern } \\
\text { Med, USA }\end{array}$ & $\begin{array}{l}\text { Building Equity into } \\
\text { Quality Improvement: } \\
\text { Reducing Socioeconomic } \\
\text { Disparities in Colorectal } \\
\text { Cancer Screening }\end{array}$ & $\begin{array}{l}\text { To determine if } \\
\text { implementation of a } \\
\text { system-wide screening } \\
\text { intervention could re- } \\
\text { duce disparities in the } \\
\text { setting of overall im- } \\
\text { proved screening rates }\end{array}$ & $\begin{array}{l}18 \text { primary care practice } \\
\text { sites around Boston, MA, } \\
\text { affiliated with the same } \\
\text { practice-based research } \\
\text { network }\end{array}$ & $\begin{array}{l}\text { Interrupted } \\
\text { time series }\end{array}$ & $\begin{array}{l}\text { Conceptual model } \\
\text { of primary care } \\
\text { delivery }\end{array}$ & $\begin{array}{l}\text { Workflow } \\
\text { modification }\end{array}$ \\
\hline $\begin{array}{l}\text { Chiang, J Oncol } \\
\text { Pract, 2015, USA }\end{array}$ & $\begin{array}{l}\text { Incorporating Patient- } \\
\text { Reported Outcomes to Im- } \\
\text { prove Emotional Distress } \\
\text { Screening and Assessment } \\
\text { in an Ambulatory Oncolo- } \\
\text { gy Clinic }\end{array}$ & $\begin{array}{l}\text { To improve emotional } \\
\text { distress screening and } \\
\text { assessment in } \\
\text { ambulatory oncology } \\
\text { clinics }\end{array}$ & $\begin{array}{l}\text { Smilow Cancer Hospital at } \\
\text { Yale Cancer Center in } \\
\text { New Haven, Connecticut } \\
\text { and two affiliated clinics }\end{array}$ & $\begin{array}{l}\text { Single group } \\
\text { pre-test post- } \\
\text { test design }\end{array}$ & None & $\begin{array}{l}\text { Workflow } \\
\text { modification; } \\
\text { rapid cycle } \\
\text { testing }\end{array}$ \\
\hline $\begin{array}{l}\text { Cohen-Cline, } \\
\text { Medical Care, } \\
\text { 2014, USA }\end{array}$ & $\begin{array}{l}\text { Use of Interactive Voice } \\
\text { Response (IVR) to Im- } \\
\text { prove Colorectal Cancer } \\
\text { (CRC) Screening }\end{array}$ & $\begin{array}{l}\text { To understand whether } \\
\text { IVR could be effective } \\
\text { to engage individuals } \\
\text { overdue for CRC } \\
\text { screening in } \\
\text { community practice } \\
\text { settings and to } \\
\text { determine if the effect } \\
\text { would persist over time }\end{array}$ & $\begin{array}{l}\text { Men and women aged } 50- \\
81 \text { years who were not } \\
\text { adherent to CRC screen- } \\
\text { ing, were insured by } \\
\text { Group Health in Washing- } \\
\text { ton State, and had a pri- } \\
\text { mary care physician who } \\
\text { was a member of that } \\
\text { network }\end{array}$ & RCT & None & $\begin{array}{l}\text { Workflow } \\
\text { modification }\end{array}$ \\
\hline $\begin{array}{l}\text { Fasola, 2014, } \\
\text { BMC Health } \\
\text { Services } \\
\text { Research, Italy }\end{array}$ & $\begin{array}{l}\text { Drug waste minimization } \\
\text { as an effective strategy of } \\
\text { cost-containment in oncol- } \\
\text { ogy }\end{array}$ & $\begin{array}{l}\text { To evaluate the impact } \\
\text { of a drug waste } \\
\text { reduction protocol on } \\
\text { drug waste } \\
\text { expenditures }\end{array}$ & $\begin{array}{l}\text { Department of Oncology } \\
\text { at the University Hospital } \\
\text { of Udine }\end{array}$ & $\begin{array}{l}\text { Single group } \\
\text { pre-test post- } \\
\text { test }\end{array}$ & None & $\begin{array}{l}\text { Guideline or } \\
\text { protocol } \\
\text { development }\end{array}$ \\
\hline $\begin{array}{l}\text { Jackman, J Oncol } \\
\text { Pract, 2017, USA }\end{array}$ & $\begin{array}{l}\text { Cost and Survival } \\
\text { Analysis Before and After } \\
\text { Implementation of Dana- } \\
\text { Farber Clinical Pathways } \\
\text { for Patients with Stage IV }\end{array}$ & $\begin{array}{l}\text { To explore the clinical } \\
\text { and financial impact of } \\
\text { the creation and } \\
\text { implementation of a } \\
\text { lung cancer pathway }\end{array}$ & $\begin{array}{l}\text { Patients who were } \\
\text { diagnosed with stage IV } \\
\text { NSCLC and treated within } \\
\text { the Dana Farber Cancer } \\
\text { Institute Network }\end{array}$ & $\begin{array}{l}\text { Single group } \\
\text { pre-test post- } \\
\text { test design }\end{array}$ & None & $\begin{array}{l}\text { Guideline or } \\
\text { protocol } \\
\text { development; } \\
\text { decision support }\end{array}$ \\
\hline
\end{tabular}


Table 3. (continued)

\begin{tabular}{|c|c|c|c|c|c|c|}
\hline \multicolumn{7}{|c|}{ Studies categorized as implementation science } \\
\hline $\begin{array}{l}\text { Author, journal, } \\
\text { year, country }\end{array}$ & Title & Objective(s) & Setting & $\begin{array}{l}\text { Evaluation } \\
\text { design }\end{array}$ & Use of theory & $\begin{array}{l}\text { Approaches to } \\
\text { practice change }\end{array}$ \\
\hline & $\begin{array}{l}\text { Non-Small-Cell Lung } \\
\text { Cancer (NSCLC) }\end{array}$ & & & & & \\
\hline $\begin{array}{l}\text { Keng, J Oncol } \\
\text { Pract, 2015, USA }\end{array}$ & $\begin{array}{l}\text { Reducing Time to } \\
\text { Antibiotic Administration } \\
\text { (TTA) for Febrile Neutro- } \\
\text { penia (FN) in the Emer- } \\
\text { gency Department }\end{array}$ & $\begin{array}{l}\text { To assess whether } \\
\text { implementation of an } \\
\text { FN pathway reduced } \\
\text { antibiotic delays and } \\
\text { provided improved } \\
\text { quality of care for } \\
\text { patients, and to identify } \\
\text { value in prompt TTA }\end{array}$ & $\begin{array}{l}\text { Adults patients with cancer } \\
\text { who presented to the } \\
\text { Cleveland Clinic } \\
\text { emergency department }\end{array}$ & $\begin{array}{l}\text { Single group } \\
\text { pre-test post- } \\
\text { test design and } \\
\text { cross-sectional } \\
\text { design }\end{array}$ & None & $\begin{array}{l}\text { Guideline or } \\
\text { protocol } \\
\text { development; } \\
\text { education/ } \\
\text { training; } \\
\text { workflow modi- } \\
\text { fication }\end{array}$ \\
\hline $\begin{array}{l}\text { Montero, J Oncol } \\
\text { Pract, 2016, USA }\end{array}$ & $\begin{array}{l}\text { Reducing Unplanned } \\
\text { Medical Oncology } \\
\text { Readmissions by } \\
\text { Improving Outpatient Care } \\
\text { Transitions: A Process } \\
\text { Improvement Project at the } \\
\text { Cleveland Clinic }\end{array}$ & $\begin{array}{l}\text { To examine the impact } \\
\text { of (1) outpatient } \\
\text { follow-up appointments } \\
\text { within } 5 \text { days of dis- } \\
\text { charge and (2) oncolo- } \\
\text { gy nurse coordinator } \\
\text { callbacks within } 48 \mathrm{~h} \\
\text { of discharge on un- } \\
\text { planned readmission } \\
\text { rates }\end{array}$ & $\begin{array}{l}\text { Palliative medicine and } \\
\text { solid tumor oncology } \\
\text { inpatient services at the } \\
\text { Cleveland Clinic }\end{array}$ & $\begin{array}{l}\text { Interrupted } \\
\text { time series }\end{array}$ & None & $\begin{array}{l}\text { Education/ } \\
\text { training; } \\
\text { workflow } \\
\text { modification }\end{array}$ \\
\hline $\begin{array}{l}\text { Reddeman, J } \\
\text { Oncol Prac, 2016, } \\
\text { Canada }\end{array}$ & $\begin{array}{l}\text { Improving the Quality of } \\
\text { Radiation Treatment (RT) } \\
\text { for Patients in Ontario: } \\
\text { Increasing Peer Review } \\
\text { Activities on a Jurisdic- } \\
\text { tional Level Using a } \\
\text { Change Management Ap- } \\
\text { proach }\end{array}$ & $\begin{array}{l}\text { Assess the impact of } \\
\text { the change } \\
\text { management initiative } \\
\text { on uptake and quality } \\
\text { of RT peer review }\end{array}$ & $\begin{array}{l}\text { RT teams in Cancer Care } \\
\text { Ontario (CCO)'s } 14 \\
\text { regional cancer centers }\end{array}$ & $\begin{array}{l}\text { Single group } \\
\text { pre-test post- } \\
\text { test }\end{array}$ & None & $\begin{array}{l}\text { Education/ } \\
\text { training; } \\
\text { feedback }\end{array}$ \\
\hline $\begin{array}{l}\text { Wahlberg, BMC } \\
\text { Health Serv Res, } \\
2015 \text {, Norway }\end{array}$ & $\begin{array}{l}\text { Impact of Referral } \\
\text { Templates on Quality of } \\
\text { Referrals from Primary to } \\
\text { Secondary Care: a cluster } \\
\text { randomized controlled trial }\end{array}$ & $\begin{array}{l}\text { To assess the effects of } \\
\text { a referral template } \\
\text { intervention on quality } \\
\text { of referrals for various } \\
\text { conditions, including } \\
\text { suspected colorectal } \\
\text { cancer }\end{array}$ & $\begin{array}{l}14 \text { primary care practices } \\
\text { served by University } \\
\text { Hospital of North Norway, } \\
\text { Harstad }\end{array}$ & Cluster RCT & & $\begin{array}{l}\text { Education/ } \\
\text { training; } \\
\text { feedback; } \\
\text { guideline or } \\
\text { protocol } \\
\text { development }\end{array}$ \\
\hline
\end{tabular}

demonstrate a care delivery gap in the setting under study, ${ }^{12,14,16,17}$ and 2/10 referenced a system-wide initiative that prompted program development. ${ }^{16,17}$

Overall, approaches to support practice change were similar across study categories (Table 3 ). Common practice change strategies included education or training of clinicians and staff (4/10 improvement science and 8/10 implementation science) and performance monitoring and feedback to support clinician or staff behavior change $(2 / 10$ improvement science and 3/10 implementation science). Both fields used clinical decision support, workflow modifications (e.g., development of patient registries and systems for patient outreach), and rapid cycle testing. Clinical guideline or protocol development and distribution was used in 4/10 improvement science studies ${ }^{21,23,25,26}$ but no implementation science studies. In general, implementation science studies provided more detail about their approaches to practice change. For example, descriptions of clinician or staff training in implementation science studies contained more specificity about the specific approach to training (e.g., academic detailing), its venue, frequency, and resources provided.

\section{DISCUSSION}

The fields of improvement science and implementation science have complementary goals but arose from different philosophical underpinnings. The fields have historically interacted sporadically, remaining relatively isolated from one another as they have developed. ${ }^{4}$ We hypothesized that each field has qualities the other could benefit from, and that aligning and cross-fertilizing the fields could lead to more rapid advancement in cancer care delivery. To that end, we reviewed 20 highly cited implementation science and improvement science studies relating to cancer care and found that across the two fields, studies used different terms to describe the program under study (e.g., strategy vs. intervention), and provided differing amounts of detail about the local context surrounding program development and about specific program components. However, they had similar objectives, used similar methods, and employed common approaches to changing practice. In terms of the overall scientific development of each field, we noted only two studies from each category used a theoretical or conceptual model to develop the program under study. These findings lead us to several 
practical observations about the commonalities and distinctions between improvement and implementation science.

First, we observed a number of important similarities between the two categories of studies, particularly with respect to their objectives, methods (including setting and evaluation design), and approaches to practice change. Regarding objectives, most studies, regardless of category, sought to improve the uptake of evidence-based and/or guideline recommended programs or practices. With respect to setting, improvement science is often described as being location-specific, while implementation science is often described as focusing on generalizable mechanisms of change across locations. ${ }^{4,} 31$ Yet, nearly all (16/20) studies included in our review were conducted across multiple sites. In most cases, sites were described as being part of the same health care system or network. Regarding study design, improvement science has been described as highly pragmatic, potentially at the cost of attributing observed improvements to the intervention under study, while the field of implementation science is often described as scientific and research-oriented. ${ }^{31}$ Yet the majority of studies from both fields used fairly basic observational methods and therefore were limited in terms of their ability to establish that observed outcomes resulted from the program under study. In recognition of this limitation, the Standards for Quality Improvement Reporting Excellence (SQUIRE) 2.0 guidelines ${ }^{3}$ - published in 2015-emphasize that studies should use methods to establish that observed outcomes were due to the intervention(s) of interest. The Standards for Reporting Implementation Studies (STaRI) guidelines, published in 2017, contain similar language.

Second, the two disciplines have historically been described as taking different approaches to promote practice change (e.g., adapting industrial-based improvement techniques for improvement science and behavioral science techniques for implementation science). ${ }^{31}$ However, in this review, we identified that several approaches to practice change are employed across both improvement science and implementation science studies. For example, education/training is recognized as a common implementation strategy in the implementation science field ${ }^{32}$ but was also used in nearly half of studies categorized as improvement science. Another example is rapid cycle improvement. Although an established improvement science method derived from the Institute for Healthcare Improvement's "Model for Improvement,"33 rapid cycle improvement was also employed in one of the implementation science studies included in our review.

Third, despite their similarities, improvement science and implementation science studies differed with respect to the terminology they used to describe the program under study. Specifically, most implementation science studies used the term "strategy" and most improvement science studies used the term "intervention." We also noted differences with respect to the amount of information provided about the context in which gaps in care were identified and prioritized, and solutions developed, with improvement science studies generally providing more information about these processes. On the other hand, implementation science studies tended to provide more specificity about approaches to practice change.

Finally, our findings suggest that the level of scientific development of both fields is similar. In particular, only two studies from each category used theory. The application of theory has the potential to shorten the time needed to develop interventions, optimize intervention design, identify factors necessary for intervention success, and to enhance learning from these efforts. ${ }^{34-38}$ Both the SQUIRE 2.0 and STaRI guidelines emphasize the importance of applying theory to understand the problem of interest and to develop interventions to address that problem. ${ }^{3,10}$ It is important to note, however, that SQUIRE 2.0 and STaRI guidelines were published in 2015 and 2017, respectively. Possibly as a result of our focus on more frequently cited articles, several of the studies included in our review were published in or before 2015. More recently, published studies not eligible for inclusion in our targeted review may better align with these standards.

Our study has several limitations. First and foremost, our review is relatively limited in scope as a function of our study objective, which was to generate preliminary data to inform future efforts to enhance alignment between improvement science and implementation science in cancer care. We limited our search to 17 journals identified by a panel of experts as publishers of implementation science or improvement studies, and we focused specifically on improvement science and implementation science studies in the field of cancer care delivery. Among implementation science and improvement science studies relating to cancer care, we purposively selected recently published and higher-impact studies. Consistent with commonly used standards, ${ }^{8}, 9$ higher-impact studies were defined as those that were more frequently cited. It is important to note, however, that the average number of citations for included studies was 8 , which is relatively low, likely as a result of our concurrent focus on studies that were published between 2014 and 2019. Without the publication date restriction, we expect that the average number of citations included in our review would have been slightly higher. Finally, our results may not generalize to other cancer-related implementation or improvement science studies, or to studies conducted in other clinical contexts (e.g., behavioral health). However, as the first article, to our knowledge, to empirically compare published studies from each field, our work represents an important first step toward improving alignment between and enhancing the potential of both disciplines for positively impacting cancer care.

The extent of overlap that we observed in the scope and methodology of cancer-related improvement science and implementation science studies highlights opportunities to better align the two fields. The fields are already quite close in several respects, suggesting that stronger alignment has the potential to not only reduce duplication but also, more importantly, to introduce synergies that enhance the potential of both 
fields to improve care. By drawing on developed methods from each field rather than re-developing approaches, work can proceed more rapidly. For example, a combined approach might incorporate methods from improvement science for engaging local leadership to identify and prioritize gaps in delivery of evidence-based cancer care, and then use implementation science frameworks to apply or develop strategies to address those gaps. In addition, the iterative nature of improvement science may facilitate the adaption of as evidence-based interventions and/or implementation strategies as they are implemented in practice. ${ }^{39}$

We noted several instances from the studies reviewed where a more synergistic approach may have benefitted study authors' efforts to improve cancer care delivery. For example, one of the implementation science studies we reviewed (Stock et al.) ${ }^{17}$ examined the impact of two sequential implementation strategies - one targeting primary care providers (PCP) and the other targeting patients directly - on patients' uptake of follow-up colonoscopy after a positive fecal occult blood test. The authors observed no increase in colonoscopy uptake in the 8-month period following implementation of the PCP-directed strategy. This study might have benefitted from the inclusion of improvement science methodology, particularly rapid cycle testing, to optimize the PCP-directed implementation strategy.

In addition, a study by Berkowitz et al. ${ }^{19}$ tested the impact of a population management intervention on overall rates of colorectal cancer screening and on disparities in screening by educational attainment. The authors observed a $3 \%$ increase in screening completion overall, and a modest $(<1 \%$ decrease) in screening disparities. As acknowledged by the study authors, systematically assessing and targeting the unique challenges that patients with lower educational attainment face may have reduced disparities to a greater degree. For example, formative research guided by an implementation science framework - such as the Consolidated Framework for Implementation Research ${ }^{40}$ - may have revealed that factors at levels beyond patients and providers indirectly contribute to disparities in cancer screening, informing the development of a more comprehensive intervention. ${ }^{41}$

Future studies aiming to improve quality of cancer care should ideally involve consideration of methodological approaches from both disciplines at the research design stage. We suggest several steps that may facilitate such alignment, including terminology mapping to clarify differences and unify terms. We also suggest explicit sharing through the development of co-developed standards for rigor in study design and reporting. Funding opportunities are needed that encourage joint leadership of research projects to facilitate novel collaborations that leverage the complementary expertise of implementation and improvement scientists. More broadly, strategies to train, support, and incentivize professionals to work across improvement science and implementation science are critically needed to maximize the potential of both fields to fulfill the shared goal of effecting rapid, positive change in cancer care delivery.
Corresponding Author: Devon K. Check, PhD; Department of Population Health Sciences and Duke Cancer Institute, Duke University Medical Center, Durham, NC, USA (e-mail: devon.check@duke. edu).

Funding This work was supported by the Mentored Training in Dissemination \& Implementation Research in Cancer Program, National Cancer Institute grant 5R25CA171994 (principal investigator Brownson), and a Cancer Prevention, Control, Behavioral Sciences, and Populations Sciences Career Development Award from the National Cancer Institute (KO7CA211971 to M.M.D.)

\section{Compliance with Ethical Standards:}

Conflict of Interest: Dr. Zullig reports grants from the PhRMA Foundation, grants from Proteus Digital Health, and other funding from Novartis, all outside the submitted work. Dr. Davis reports funding from NCI, during the conduct of the study. The authors have no other conflicts to report.

\section{REFERENCES}

1. Institute of Medicine: Delivering High-Quality Cancer Care: Charting a New Course for a System in Crisis. Washington, DC, The National Academies Press, 2013.

2. Sullivan R, Pramesh CS, Booth CM. Cancer patients need better care, not just more technology. Nature. 2017;549(7672):325-328.

3. Ogrinc G, Davies L, Goodman D, Batalden P, Davidoff F, Stevens D. SQUIRE 2.0 (Standards for QUality Improvement Reporting Excellence): revised publication guidelines from a detailed consensus process. $B M J$ Qual Saf. 2016;25(12):986-992.

4. Koczwara B, Stover AM, Davies L, et al. Harnessing the Synergy Between Improvement Science and Implementation Science in Cancer: A Call to Action. J Oncol Pract. 2018;14(6):335-340.

5. Davidoff F, Dixon-Woods M, Leviton L, Michie S. Demystifying theory and its use in improvement. BMJ Qual Saf. 2015;24(3):228-238.

6. Adesoye T, Greenberg CC, Neuman HB. Optimizing Cancer Care Delivery through Implementation Science. Front Oncol. 2016;6:1.

7. Ouzzani, M., et al. (2016). "Rayyan-a web and mobile app for systematic reviews." Syst Rev 5(1): 210.

8. Aragon AM. A measure for the impact of research. Sci Rep. 2013;3:1649.

9. Lehmann S, Jackson AD, Lautrup BE. Measures for measures. Nature. 2006;444(7122):1003-1004.

10. Pinnock H, Barwick M, Carpenter CR, et al. Standards for Reporting Implementation Studies (StaRI): explanation and elaboration document. BMJ Open. 2017;7(4):e013318.

11. Glanz K, Escoffery C, Elliott T, Nehl EJ. Randomized Trial of Two Dissemination Strategies for a Skin Cancer Prevention Program in Aquatic Settings. Am J Public Health. 2015;105(7):1415-1423.

12. Vanderpool RC, Breheny PJ, Tiller PA, et al. Implementation and Evaluation of a School-Based Human Papillomavirus Vaccination Program in Rural Kentucky. Am J Prev Med. 2015;49(2):317-323.

13. Arrossi S, Paolino M, Thouyaret L, Laudi R, Campanera A. Evaluation of scaling-up of HPV self-collection offered by community health workers at home visits to increase screening among socially vulnerable underscreened women in Jujuy Province, Argentina Implement Sci. 2017;12(1): 17

14. Bharel M, Santiago ER, Forgione SN, Leon CK, Weinreb L. Eliminating health disparities: innovative methods to improve cervical cancer screening in a medically underserved population. Am J Public Health. 2015; 105 Suppl 3:S438-442.

15. Mader EM, Fox CH, Epling JW, et al. A Practice Facilitation and Academic Detailing Intervention Can Improve Cancer Screening Rates in Primary Care Safety Net Clinics. J Am Board Fam Med. 2016;29(5):533542.

16. Shelton JB, Ochotorena L, Bennett C, et al. Reducing PSA-Based Prostate Cancer Screening in Men Aged 75 Years and Older with the Use of Highly Specific Computerized Clinical Decision Support. J Gen Intern Med. 2015;30(8):1133-1139.

17. Stock D, Rabeneck L, Baxter NN, et al. Mailed participant reminders are associated with improved colonoscopy uptake after a positive FOBT 
result in Ontario's ColonCancerCheck program. Implement Sci. 2015;10:35.

18. Tu SP, Chun A, Yasui Y, et al. Adaptation of an evidence-based intervention to promote colorectal cancer screening: a quasiexperimental study. Implement Sci. 2014;9:85.

19. Berkowitz SA, Percac-Lima S, Ashburner JM, et al. Building Equity Improvement into Quality Improvement: Reducing Socioeconomic Disparities in Colorectal Cancer Screening as Part of Population Health Management. J Gen Intern Med. 2015;30(7):942-949.

20. Cohen-Cline H, Wernli KJ, Bradford SC, Boles-Hall M, Grossman DC. Use of interactive voice response to improve colorectal cancer screening. Med Care. 2014;52(6):496-499.

21. Wahlberg $\mathbf{H}$, Valle PC, Malm S, Broderstad AR. Impact of referral templates on the quality of referrals from primary to secondary care: a cluster randomised trial. BMC Health Serv Res. 2015;15:353.

22. Reddeman L, Foxcroft S, Gutierrez E, et al. Improving the Quality of Radiation Treatment for Patients in Ontario: Increasing Peer Review Activities on a Jurisdictional Level Using a Change Management Approach. J Oncol Pract. 2016;12(1):81-82, e61-70.

23. Jackman DM, Zhang Y, Dalby C, et al. Cost and Survival Analysis Before and After Implementation of Dana-Farber Clinical Pathways for Patients With Stage IV Non-Small-Cell Lung Cancer. J Oncol Pract. 2017;13(4):e346-e352.

24. Fouad MN, Acemgil A, Bae S, et al. Patient Navigation As a Model to Increase Participation of African Americans in Cancer Clinical Trials. $J$ Oncol Pract. 2016;12(6):556-563.

25. Fasola G, Aprile G, Marini L, Follador A, Mansutti M, Miscoria M. Drug waste minimization as an effective strategy of cost-containment in oncology. BMC Health Serv Res. 2014;14:57.

26. Keng MK, Thallner EA, Elson P, et al. Reducing Time to Antibiotic Administration for Febrile Neutropenia in the Emergency Department. $J$ Oncol Pract. 2015;11(6):450-455.

27. Walling AM, D'Ambruoso SF, Malin JL, et al. Effect and Efficiency of an Embedded Palliative Care Nurse Practitioner in an Oncology Clinic. $J$ Oncol Pract. 2017;13(9):e792-e799.

28. McCarter K, Baker AL, Britton B, et al. Effectiveness of clinical practice change strategies in improving dietitian care for head and neck cancer patients according to evidence-based clinical guidelines: a steppedwedge, randomized controlled trial. Transl Behav Med. 2018;8(2):166174.

29. Chiang AC, Buia Amport S, Corjulo D, Harvey KL, McCorkle R Incorporating patient-reported outcomes to improve emotional distress screening and assessment in an ambulatory oncology clinic. $J$ Oncol Pract. 2015;11(3):219-222.
30. Montero AJ, Stevenson J, Guthrie AE, et al. Reducing Unplanned Medical Oncology Readmissions by Improving Outpatient Care Transitions: A Process Improvement Project at the Cleveland Clinic. $J$ Oncol Pract. 2016; 12(5):e594-602.

31. Mittman B. Lecture presented: Implementation Science and Improvement Science: Differences, Similarities and Synergies at the Training Institute for Dissemination and Implementation Research in Health; July 26-31, 2015; Pasadena, CA.

32. Powell BJ, Waltz TJ, Chinman MJ, et al. A refined compilation of implementation strategies: results from the Expert Recommendations for Implementing Change (ERIC) project. Implement Sci. 2015;10:21.

33. Langley GL, Moen R, Nolan KM, Nolan TW, Norman CL, Provost LP. The Improvement Guide: A Practical Approach to Enhancing Organizational Performance (2nd edition). San Francisco: Jossey-Bass Publishers; 2009.

34. Foy R, Ovretveit J, Shekelle PG, et al. The role of theory in research to develop and evaluate the implementation of patient safety practices. BMJ Qual Saf. 2011;20(5):453-459.

35. Improved Clinical Effectiveness through Behavioural Research G. Designing theoretically-informed implementation interventions. Implement Sci. 2006; 1:4.

36. French SD, Green SE, O'Connor DA, et al. Developing theory-informed behaviour change interventions to implement evidence into practice: a systematic approach using the Theoretical Domains Framework. Implement Sci. 2012;7:38.

37. Marshall M, Pronovost P, Dixon-Woods M. Promotion of improvement as a science. Lancet. 2013;381(9864):419-421.

38. Grol RP, Bosch MC, Hulscher ME, Eccles MP, Wensing M. Planning and studying improvement in patient care: the use of theoretical perspectives. Milbank Q. 2007;85(1):93-138.

39. Chambers DA, Norton WE. The Adaptome: Advancing the Science of Intervention Adaptation. Am J Prev Med. 2016;51(4 Suppl 2):S124-131.

40. Damschroder LJ, Aron DC, Keith RE, Kirsh SR, Alexander JA, Lowery JC. Fostering implementation of health services research findings into practice: a consolidated framework for advancing implementation science. Implement Sci. 2009;4:50.

41. Chinman M, Woodward EN, Curran GM, Hausmann LRM. Harnessing Implementation Science to Increase the Impact of Health Equity Research. Med Care. 2017;55 Suppl 9 Suppl 2:S16-S23.

Publisher's Note: Springer Nature remains neutral with regard to jurisdictional claims in published maps and institutional affiliations. 